\title{
Malignant Lip Neoplasm
}

National Cancer Institute

\section{Source}

National Cancer Institute. Malignant Lip Neoplasm. NCI Thesaurus. Code C7485.

A primary or metastatic malignant neoplasm involving the lip. 